\title{
Häpeä suomalaisten mielisairaalamuistoissa
}

\author{
Karoliina Maanmieli
}

Hulluus stigmatisoi. Ensimmäisellä kerralla sen huomasi selkeimmin. Tunsin, kuinka kaikki tiesivät, vaikkei todellisuudessa kukaan. Nyt alkaa olla jo omaksunut olevansa hullu. (SKS 454, sairaalajakso 2010-luvulla.)

Yllä olevassa tekstissä kirjoitushetkellä psykiatrisessa sairaalahoidossa ollut mies kertoo oman kokemuksensa sairaalaan joutumisen häpeäleimasta. Ensimmäisen sairaalajakson aikana häpeä ja sairaalahoidon ympärille kietoutunut stigma oli helppo havaita, mutta jaksojen toistuessa hulluudesta' ${ }^{1}$ on tullut osa identiteettiä. Teksti on osa Muistoja ja kokemuksia mielisairaalasta -aineistoa, johon on kerätty muistelukirjoituksia suomalaisten mielisairaalakokemuksista ${ }^{2}$. Aineisto koottiin vuosina 2014-2015 Kulttuurisen mielenterveystutkimusverkoston ja Suomalaisen Kirjallisuuden Seuran (SKS) kansarunousarkiston yhteistyönä. Keruukutsu julkaistiin SKS:n kotisivuilla, sanoma- ja aikakauslehdissä sekä lähetettiin mielenterveysyhdistyksiin ja joihinkin hoitoyksiköihin. Tutkimme mielisairaalamuistoja Koneen Säätiön rahoittamassa Muistoihin kaivertuneet tilat (2017-2020) -hankkeessamme viiden eri alan tutkijan voimin.

Tässä katsauksessa keskityn esittelemään muisteluaineistossa kuvattua häpeää. Häpeää voidaan tarkastella muun muassa kehityspsykologian tai affektiteorian kautta (Tomkins 1963, Reckhardt ja Ikonen 1994), kuten myös sosiaalisesta näkökulmasta (Paukkunen 2013, 18). Kehityspsykologian piirissä ajatellaan, että häpeän tunteet alkavat muodostua jo vauvaiässä reaktiona hyväksyvän vastavuoroisuuden puutteeseen (Reckhardt ja Ikonen 1994), ja häpeäkokemuksien toistuessa läpi lapsuuden ja nuoruuden ne alkavat vaikuttaa ihmisen identiteettiin. Häpeä on monella tavalla hyödyllinen tunne, mutta jos se valtaa liikaa alaa muilta tunteilta, se voi alkaa hallita elämää. Tällaista häpeää kutsutaan sisäistetyksi häpeäksi, joka on tullut osaksi minäkuvaa ja synnyttänyt kokemuksen syvästä arvottomuudesta. Se liittyy varhaisiin kokemuksiin ja on yhteydessä myöhemmän elämän psyykkisiin vaikeuksiin.

1 Kulttuurisen mielenterveystutkimuksen piirissä hulluus käsitetään sosiaalisesti konstruoituna käsitteenä ja ilmiönä, joka vain osittain kytkeytyy psykiatriaan. Se kokoaa yhteen sellaisia toiminnan ja olemisen muotoja, jotka on eri konteksteissa koettu epätavallisiksi tai omituisiksi. (Kinnunen ja Hänninen 2016; Jäntti et al. 2019.) Termin käyttö voidaan kuitenkin myös kokea loukkaavaksi. Muistelutekstien kirjoittajat ovat yleisesti käyttäneet hulluus-termiä, usein itse omaksuttuna voimauttavana kapinallisen ryhmäidentiteetin merkkinä (vrt. Jäntti et al. 2019).

2 Käytän mielisairaala-termiä muistelukeruun otsikon mukaisesti, vaikka osa muisteluteksteistä kuvaakin aikaa, jolloin on jo käytetty termiä "psykiatrinen sairaala". Kirjoittajat ovat käyttäneet teksteissään mielisairaala-termiä, ehkä osittain keruukutsun ohjaamina. 
Toinen häpeän tyyppi on tapahtumasidonnainen häpeä, joka liittyy tiettyyn tekoon tai traumaattiseen tapahtumaan. (Janoff-Bulman 1979, 1807-1809.) Kulttuurintutkimuksen alueella häpeän tutkimus on varsinkin feministisissä tutkimustraditioissa seurannut affektiteorian jalanjälkiä. Feministinen tutkimus tarkastelee häpeää kehittämällä uudenlaisia tapoja ja käsitteitä, joiden avulla voidaan käsitellä subjektia ruumiillisesti paikantuneena ja relationaalisena. (Kainulainen ja Parente-Čapkova 2011.) Affektiteoria ja kehityspsykologia suhtautuvat häpeään pääsääntöisesti yksilön hyvinvointia uhkaavana tunteena ja liittävät sen monenlaiseen psyykkiseen oirehdintaan (Paukkunen 2013, 18). Sosiaalitieteiden näkökulmasta tarkasteltuna häpeä kytkeytyy usein muihin itseä arvioiviin tunteisiin (eng. selfconscious emotions) kuten syyllisyyteen, nolostumiseen ja nöyryytykseen. Näille tunteille on yhteistä se, että niiden kautta ihminen arvioi itseään suhteessa yhteisöstä sisäistettyihin normeihin. (Niedenthal et al. 2006, 96.)

Tässä katsauksessa tarkastelen häpeää yksilön kokemuksena, johon liittyy sosiaalisia ja kulttuurisia elementtejä. Muistelukerronnan tutkimuksessa voidaan päästä käsiksi erilaisiin käsityksiin häpeästä, ja näin se tuo häpeän tarkasteluun oivan lisän psykologisten ja muiden sosiaalitieteiden näkökulmien rinnalle. Ympäröivä maailma vaikuttaa paitsi yksilön persoonallisuuden muodostumiseen, myös kulttuurisesti määrittyvien puhetapojen ja asemien valikoimaan. (Leeming ja Boyle 2014, 381, 390.)

Kirjoitetut muistelutekstit ovat häpeän tarkastelun kannalta mielenkiintoinen tutkimuskohde, koska häpeä liittyy usein nimenomaan vaikeasti kerrottaviin tarinoihin, kokemuksiin ja tunteisiin (Eronen 2012, 46). Näin se kytkeytyy myös mielenterveyden ongelmiin, joilla suomalaisessa kulttuurissa on vahva tabuluonne. Toisaalta psyykkisen diagnoosin saaminen ja sairaalahoitoon joutuminen puolestaan lisäävät häpeäntunteita - omaa tai perheenjäsenen psyykkistä sairastumista leimaa kulttuurissamme usein syvä häpeä, salailu ja syyllisyydentunteet (esim. Joutsenniemi 2011; Lidman 2011). Suomessa häpeän tarkastelun kulttuurintutkimuksen näkökulmasta voi katsoa käynnistyneen historioitsija Juha Siltalan (1994) suomalaisen miehen häpeää käsittelevästä Miehen kunnia -teoksesta. Sittemmin häpeästä on tehty tutkimuksia muun muassa psykologian (Silfver-Kuhalampi 2009; Malinen 2010) sekä rikoshistorian (Lidman 2011) näkökulmista. Kulttuurintutkimuksen piirissä peruskatsauksena aiheeseen voidaan pitää Häpeä vähän!-kokoomateosta (Kainulainen ja Parente-Čapkova 2011), joka keskittyy häpeän seksuaalisiin ja rikoshistoriallisiin kysymyksiin. Teoksessa on tarkasteltu ihmisten omakohtaisia, traumaattisia häpeäkokemuksia, mutta myös häpeää sosiaalisena ilmiönä esimerkiksi kulttuuristen normien noudattamattomuuden tai häpeän ylisukupolvisuuden näkökulmasta.

Suomessa on tutkittu myös mielenterveysongelmiin kytkeytyvää häpeää. Sosiaalipolitiikan tutkija Anna Kulmala (2006) pohtii leimatun identiteetin ja toiseuden kokemuksia muun muassa mielenterveysongelmien kannalta. Muutkin viimeaikaiset psyykkisen sairauden kulttuurista rakentumista pohtivat tutkimukset (esim. Kinnunen 2013) käsittelevät häpeän teemoja. Teoksessa Irti häpeäleimasta (Korkeila et al. 2011) tarkastellaan häpeää niin hoitohenkilökunnan, omaisten kuin mielenterveyskuntoutujienkin näkökulmasta. Kulttuurisen mielenterveystutkimuksen tiimoilta tutkimuskirjallisuuteen tuo oivan lisänsä juuri julkaistu artikkelikokoelma Hulluus ja kulttuurinen mielenterveystutkimus (Jäntti et al. 2019), jonka monet artikkelit sivuavat myös mielenterveysongelmiin kytkeytyvää häpeää. 
Tarkastelen muisteluaineistoa paitsi kirjoittamisen tutkijana, myös entisenä mielenterveysalan työntekijänä ja kirjallisuusterapiaohjaajana. Työurani aikana olen nähnyt, miten kokonaisvaltainen häpeä mielenterveysongelmiin usein kytkeytyy ja miten kirjallisuusterapiaryhmien osallistujat usein tarvitsevat pitkän prosessin pienryhmässä ennen kuin uskaltautuvat kirjoittamaan tai jakamaan ajatuksiaan. Tätä taustaa vasten onkin mielenkiintoista tarkastella, miten paljon prosessointia erityisesti sisäistetyn häpeän tunteet ovat jo vaatineet ennen kuin mielisairaalamuistojen kirjoittajat ovat olleet valmiita jakamaan omia muistojaan ja miten paljon häpeä sävyttää muistelutekstejä. Minua kiinnostaa myös muistelutekstin kirjoittamiseen liittyvä terapeuttinen, häpeää lieventävä vaikutus. Tutkimukseni viitekehys on kulttuurinen mielenterveystutkimus (Jäntti et al. 2019). Se asettuu osaksi hulluustutkimusta (esim. Kinnunen ja Hänninen 2016), mutta otan lähtökohdakseni hulluuden määrittelyn juuri terveyteen kytkeytyvänä kysymyksenä. Hulluustutkimuksessa psykiatria, mielisairaudet ja mielisairaalat nähdään eri asemissa olevien henkilöiden välisten kohtaamisten sekä käsitysten, käytänteiden ja ideologioiden risteyksenä. Varsinkin vastentahtoiseen sairaalahoitoon joutumiseen sekä pakkokeinojen käyttöön liittyy häpeällinen kokemus omien fyysisten rajojen ylittämisestä, kelpaamattomuudesta ja toiseudesta. Kansanperinteen tutkija Anna Kinnunen (2013) on todennut, että mielisairaalapotilaita koskevaan muistelukerrontaan liittyy usein erilaisuuden ja normaaliuden välistä rajantekoa ja mahdollista toiseuden tuottamista.

\section{Tutkimusaineisto ja menetelmät sekä eettinen pohdinta}

Päälähteenäni tässä katsauksessa käytän SKS:n mielisairaalamuistoaineistoa sekä yhtä tutkijaryhmällemme keruun jo loputtua lähetettyä muistoa. Koko aineisto koostuu 500 sivusta tekstejä, jotka on kerätty noin 90 kirjoittajalta. Tässä katsauksessa valitsin tarkasteluni kohteeksi potilaiden ja heidän omaistensa muistot, joita on aineistossa yhteensä 58. Jätin aineistostani pois henkilökunnan muistot, joita oli kokonaisuudessaan vain 11 kappaletta. Niistäkin vain harvoissa sivuttiin häpeän teemoja. Jätin tarkastelun ulkopuolelle myös henkilökunnan lasten muistot, joita taidehistorioitsija Sari Kuuva (2018) on käsitellyt laajasti omassa tutkimuksessaan ${ }^{3}$. Käsittelemäni muistot sijoittuvat eri sairaaloihin 1930-luvulta 2010-luvulle. Muistelijoita on kaikista ikäryhmistä teini-ikäisistä vanhuksiin. Joillakin muisto sijoittuu vuosikymmenien päähän menneisyyteen ja tuoreimmillaan muisto on kirjoitettu sairaalajakson aikana. Muistoja on kootusti kerätty ainakin kahdessa mielenterveysalan kuntoutus- ja hoitoyksikössä.

Muistelukeruun tuloksena syntyneen aineiston analyysissa on hyvä ottaa huomioon aineiston erityispiirteet: heterogeenisyys, muistinvaraisuus ja muistojen kertaamisen sekä muiden tarinoiden sekoittumisen vaikutukset omaan kokemukseen (Pöysä 2015, 18-24). Mielisairaalamuistotekstit ovat keskenään erilaisia muun muassa kieliasultaan, laajuudeltaan ja käsittelytavaltaan. Niiden pituus vaihtelee muutamista lauseista laajoihin elämäntarinoihin. Potilaiden muistelutekstejä leimaa traumaattisten mielisairaalamuistojen sanallistamisen vaikeus ja muistojen aukkoisuus, joka aineiston pohjalta selittyy osittain trauman ja siihen kytkeytyvän häpeän kautta (vrt. Maanmieli 2018a).

Sairaala-alueella asuville lapsille mielenterveyden ongelmat näyttäytyivät asuinympäristön ansiosta usein normaalina osana elämää ja ihmisyyttä, ja hulluus sai sanana myös positiivisia ja nostalgisiakin konnotaatioita. Muistoissa korostettiin enemmän sairaala-alueella asumisen suvaitsevaisuutta lisäävää vaikutusta kuin siihen liittyvää häpeää (Kuuva 2018). 
Mielisairaalamuistokeruukutsussa pyydettiin kuvaamaan esimerkiksi hoitokokemuksia, kohtaamisia sairaalassa, sairaala-ajan merkitystä ja vaikutusta elämään sekä sairaalarakennusta ympäristöineen. Ohjeistus oli tarkoituksella laadittu niin, että kirjoittajat voisivat itsenäisesti valita lähestymistapansa. Osassa tekstejä on käytetty taiteellista vapautta: niitä on kirjoitettu runojen ja aforismien muodossa ja niihin on liitetty valokuvia ja piirroksia. Näin ne ovat mahdollistaneet kirjottajilleen taiteen terapeuttisen voiman hyödyntämisen. Runossa kirjoittaja purkaa, mutta myös jäsentää itseään - runossa sanat ovat kuvia, jotka resonoivat mielen ja ruumiin eri kerroksissa mahdollistaen eheytymisen (Mertanen 2009, 252-255). Folkloristi Jyrki Pöysä (2015) korostaa väljästi laaditun keruukutsun mahdollistamaa terapeuttista merkitystä - antaahan se tilaa reflektoida omaa kokemusta sopivalta laajuudelta ja syvyydeltä.

Varsinaisena tutkimusmenetelmänäni olen käyttänyt lähilukua, joka Pöysän $(2015,25)$ mukaan soveltuu kirjoituskutsun kautta kerätyn muisteluaineiston analyysiin. Olen soveltanut lähilukua tekemällä merkintöjä muisteluteksteihin, reflektoimalla niitä kirjoittamalla sekä palaamalla teksteihin useita kertoja, jolloin aineistosta on paljastunut uusia seikkoja. Huomasin, että häpeä osoittautui yhdeksi keskeisimmäksi tunteeksi, jota muistoissa kuvattiin; joko nimeltä mainittuna tai siten, että muistelija nimesi häpeään liittyviä muita tunteita kuten nolostumista tai hoitokäytäntöjen nöyryyttävyyttä. Toisinaan häpeä ilmeni kirjoittajan kuvauksesta siitä, miten mielenterveysongelmia tai sairaalassa oloa on salailtu. Häpeää kuvattiin muistoissa paitsi suorasanaisesti, myös metaforien ${ }^{4}$ kautta.

Mielisairaaloihin liittyvät muistot ovat arkaluontoisia ja syvästi henkilökohtaisia, joten niitä käsiteltäessä tutkimuseettisten seikkojen pohdinta on tärkeää (Kallinen et al. 2015). Eettiset kysymykset liittyvät myös muistotekstien kerronnallisuuteen. Osalle kirjoittajista motiivina osallistua keruuseen on halu tallentaa ja jakaa kollektiivisesti tärkeiksi katsomansa muistot, osa taas haluaa tuoda näkyviin sairaaloiden toimintaan liittyviä epäkohtia. Valikoituneen muistitiedon tulkitseminen edellyttääkin tutkijalta sensitiivisyyttä sekä omien emansipatoristen motiivien tunnistamista (Fingerroos ja Haanpää 2006, 30-40). Itseäni tutkijana motivoi potilaiden kokemustiedon saattaminen näkyväksi. Väljästi ohjeistettuja muistelmia analysoidessa pitäisi säilyttää kirjoittajan muistokuvauksen autenttisuus, mutta suojella myös kirjoittajien yksityisyyttä ja erityislaatua (Pöysä 2015, 19-20). Siksi olen liittänyt analyysiin runsaasti otteita aineistosta.

Olen poistanut teksteistä kirjoittajien nimet heidän anonymiteettinsä turvaamiseksi. Joissain tapauksissa kirjoittaja ehkä olisi halunnut esiintyä omalla nimellään. Katsoin tässä kuitenkin parhaaksi pitäytyä otteiden nimettömyydessä toisaalta yhtenäisyyden vuoksi, toisaalta siksi että tekstit liittyvät muidenkin kuin kirjoittajiensa elämään ja kirjoittajan nimen käyttäminen mahdollistaisi myös muiden tekstissä kuvattujen ihmisten tunnistamisen.

\section{Minuuden kokemus ja häpeä}

Muistoaineistossa on paljon tekstejä, joiden kirjoittaja muistelee mielisairaaloita sekä omaisen että potilaan roolissa. Tällöin muistellut sairaalakokemukset ovat tyypillisesti ajallisesti kaukana toisistaan, ja ensimmäiset muistot sijoittuvat lapsuuden tai nuoruuden ajalle. Lapsuuteen ja nuoruuteen sijoittuvia potilaiden muistoja ovat myös ne, joissa kirjoittaja itse on Muisteluaineiston metaforia olen käsitellyt laajemmin Psykoterapia-lehdessä ilmestyneessä artikkelissani (Maanmieli 2018a). 
joutunut mielisairaalaan jo lapsena tai katsoo oman myöhemmän sairaalaan joutumisensa liittyvän lapsuuden tapahtumiin. Näitä muistelukirjoituksia tulkittaessa on muistettava, että analysoidaan aikuisen muistikuvaa lapsuuden kokemuksista, jolloin muistojen ajankohdan ja niistä kirjoittamisen välillä on usein vuosikymmenien pituinen ajallinen etäisyys (Savolainen 2015, 93). Muistoissa erottuu näin kertova minä ja kerrottu minä, vaikka puhutaankin omista kokemuksista (Pöysä 2009, 331). Kilpakeruisiin liittyy osallistujien mielissä usein vaatimus muistojen autenttisuudesta (Savolainen 2015, 161) ja jotkut aineiston muistelijoista pahoittelevatkin muistinsa aukkoja ja sitä, etteivät kykene luotettavaan ja autenttiseen kronologiseen kerrontaan (vrt. Savolainen 2015, 160).

Riippumatta siitä, kuuluuko omaan nuoruuteen psyykkistä oireilua, voi sairastumisen ja sairaalaan joutumisen uhka olla läsnä taustalla silloin, kun suvussa on paljon mielenterveyden ongelmia. Ympäröivä kulttuurinen todellisuus vaikuttaa yksilön persoonallisuuden muodostumiseen, mutta myös siihen, millaisia puhetapoja ja asemia hänellä on valittavanaan. Jos ympäristö tarjoaa yksilölle häpeän leimaamaa identiteettiä, voi tätä olla vaikeaa vastustaa. (Leeming ja Boyle 2004, 381-90.) Tämä korostuu kerrottaessa mielisairaalamuistoja, jolloin keruukutsun rajaama aihe ohjaa kerrontaa tarinallisesti ja juonellisesti korostamaan mielen sairastumisen teemaa ja liittämään omaan tarinaan mielisairaalaan liittyviä kulttuurisia tarinoita (vrt. Pöysä, 2015, 24). Lapsuuden muistelukerrontaan on katsottu liittyvän myös niin sanottua kultaistamista ja kurjistamista (esim. Makkonen 2005, 86,93; Savolainen 2015, 70-71). Folkloristi Ulla Savolainen pitää tätä menneisyyden määrittelynä sekä retorisena keinona, jolla konstruoidaan näkemystä menneisyydestä nykyisyyden ja tulevaisuuden taustoittajana.

Kun muistelija kertoo lapsuutensa aikana perheessä puhjenneesta psyykkisestä sairaudesta, hän usein kuvaa sen sävyttäneen koko hänen elämänkulkuaan ja tuottaneen voimakasta sisäistettyä häpeää. Jotkut aineistossa kuvatut lapsuuden häpeäkokemukset ovat liittyneet myös seksuaaliseen hyväksikäyttöön tai muuhun kaltoinkohteluun.

Psykiatri Claes? ? sanoi kerran 90-luvulla television Jälkiviisaat-ohjelmassa, että mielisairaaloiden suljetuilla osastoilla naisista $60 \%$ on insestin uhreja. Niinhän olin minäkin. Lisäksi olin kammottavalla tavalla pahoinpidelty koko lapsuuteni ajan. Halolla, remmillä, suurella risukarahkalla ym. hakattu. Olin ruhjeissa ja haavoilla. Ja hirvittävästi vihattu ja koko ajan hulluksi moitittu. (SKS 0404, sairaalajakso 1970-luvulla.)

Teologi Ben Malisen $(2018,18)$ mukaan häpeä siirtyy helposti sukupolvelta toiselle. Monille muistelijoille on jo lapsuudessa muodostunut käsitys, että psyykkisessä sairastumisessa ja varsinkin sairaalaan joutumisessa on jotain hävettävää. Tämä näkemys voi syntyä esimerkiksi muiden lasten kommenttien ja pilkkaamisen pohjalta:

Varhaisin muisto mielisairaalasta liittyy kesäiseen päivään, kun me ala-asteen ensimmäisillä luokilla
olevat naapurukset seisomme pienen maalaiskunnan pihatiellä ja kiistelemme jostain. Äkkiä yksi
vanhemmista pojista hermostuu ja tokaisee: "Törnävälle". Toiset innostuvat ja hokevat alakynteen jää-
neelle tytölle "Törnävälle, Törnävälle". Silloin en tiennyt että Törnävä on sadan kilometrin päässä oleva
mielisairaala. Myöhemmin kävin siellä isääni katsomassa. (SKS 0370, muiston ajankohtaa ei mainittu.)

Kaikissa muistoissa häpeän rakentumista ei yksilöidä, vaan se todetaan yleisellä tasolla yhteisesti jaettuna totuutena. Mielisairaaloihin liittyy lasten silmissä tietty mystisyys - kukaan ei ihan tarkkaan tiedä, keitä siellä on hoidossa ja miksi. Seuraavassa mielisairaalajakson 
aikaan kirjoitetussa muistossa havainnollistuu häpeän kytkeytyminen koko elämänkulkuun. Lyhyeen muistoon rakentuu muistelutekstille tyypillinen kausaalisuus ja juonellisuus (vrt. Pöysä 2015, 79). Mystisyys mielisairaiden ympäriltä on elämän varrella hävinnyt, mutta toisaalta kirjoittaja itse on ottanut kantaakseen "laitapuolen ihmisen" häpeäleiman, joka on sisäistynyt osaksi hänen identiteettiään:

Muistan, kun ensimmäistä kertaa kuulin Visalasta. Potilaat olivat jotakin kylän hulluja. Siihen liittyi salattua häpeää. Laitapuolen ihmiset. Nyt olen itse sellainen. (SKS 0454, potilas, sairaalajakso 2010-luvulla.)

\section{Potilaan läheiset ja häpeän tunteet}

Potilaiden omaiset ja läheiset tulevat aineistossa näkyviksi niin omana muistelijaryhmänään kuin potilaiden ja henkilökunnankin muistoissa. Aineiston läheispositiot ovat muutenkin moninaisia: omainen voi olla sairaalahoidossa olevan lapsi, vanhempi, sisarus tai ystävä. Myös häpeän kokemus näyttäytyy hieman erilaisena sen mukaan, mistä roolista käsin mielisairaalaa muistellaan. Aineiston avulla on mahdollista tarkastella erilaisia asemia ja näkökohtia, joita omaisten asemaan ja rooleihin psykiatrisessa sairaanhoidossa liittyy. Sisaruksen psyykkinen sairastuminen on ollut monelle muistelijalle raskas lapsuuden tai nuoruuden kokemus. Sairastumisen tuottamaan häpeään on liittynyt myös pelkoa mahdollisesta omasta sairastumisesta.

Alla oleva muisto sijoittuu jatkosodan aikaan, jolloin kirjoittajan veli joutui sairaalahoitoon rintamalla kokemiensa traumojen jälkiseurauksena. Se kuvaa osuvasti sitä kokonaisvaltaista häpeää, joka leimaa ei ainoastaan sairastuneen itsensä, vaan myös koko hänen perheensä. Historioitsija Satu Lidman $(2011,80)$ kuvaakin häpeää osuvasti stigmana, joka lattialle kaatuvan likasangon tavoin tahraa koko ympäristönsä. Jälkeenpäin sisar kertoo kokeneensa voimakasta syyllisyyttä siitä, että hylkäsi veljensä leimautumisen pelon vuoksi, eikä käynyt tervehtimässä tätä edes työskennellessään samassa sairaalassa, jossa veli oli potilaana.

\footnotetext{
Veljeni sairaus vaikutti koulunkäyntiini. Perhettämme alettiin kutsua hullujen porukaksi. [...] Äiti oli ainoa, joka piti yhteyttä veljeemme. Me muut pelkäsimme leimautumista, enkä koskaan sanonut, että veljeni on mielisairaalassa. [...] Ennen naimisiin menoa kerroin miehelleni veljeni sairaudesta. Suvun saatua tietää asiasta sain tyhmän ja hulluuteen taipuvaisen leiman, köyhän piikatytön leiman lisäksi. (SKS 0427, muiston ajankohtaa ei mainittu.)
}

Sodan kauhujen psyykkisesti sairastuttamia miehiä pidettiin yleisesti muita heikompina tai epänormaaleina, ja sairastuneiden ongelmia hävettiin ja yritettiin pitää ne perhepiirissä, jottei sitaatissa kuvattua "hullujen porukaksi" leimaamista pääsisi tapahtumaan. Useat miehen koteloivat kipeän sotakokemuksen sisälleen, eivätkä välttämättä ole halunneet koko elämänsä aikana puhua siitä kenellekään. (Kivimäki 2013; Siltala 1994.)

Useissa muissakin muistoissa kuvataan omaisten häpeävän läheisensä sairastumista ja sairaalaan joutumista. Häpeä perheenjäsenen sairastumisesta voi johtaa tämän sairaalaan joutumiseen salailuun, ja mielisairaalajaksot jäävät usein suvun puhumattomiksi salaisuuksiksi. Salassapito on joskus jopa ollut omaisille tärkeämpää kuin yhteydenpito sairastuneeseen, kuten tässä isänsä mielisairaalajaksoa muistelevan miehen lapsuusmuistossa: 
Kun olin kymmenvuotias [...] isäni olikin suljetulla osastolla, Törnävällä. Päätimme ilahduttaa isää kortilla. Valitsimme sen tarkkaan, ja osoitekenttäkin oli jo täytetty, kun äitini totesi, ettei sitä voi lähettää, muutoinhan kylillä saataisiin selville missä isä on." (SKS 0370, muiston ajankohtaa ei mainittu.)

Tässä muistossa häpeä näyttäytyy paitsi tunteena, myös yhteydenpitoa ja asiointia ohjaavana kokemuksena. Pienessä kylässä tieto leviää tai sen pelätään leviävän postitoimiston kautta. Yhteisö ei yllä olevassa esimerkissä suojaa yksilöä, vaan on häpeän tunnetta lisäävä, toimintaa rajaava kehys.

Joissain muistoissa vanhempien suhtautumistavat ovat keskenään vastakkaisia, jolloin toisen vanhemman ymmärtäväisyys kompensoi lapsensa sairautta häpeävän vanhemman haitallista vaikutusta:

Aina oli tärkeätä, miltä näytti ulospäin. Oikeastaan se oli vain äitini projekti. Hän ei koskaan hyväksynytkään, että minulla mitään mielenterveydellisiä ongelmia edes oli. [...] Oikea täydellinen kulissi-ihminen, jolle vieläkin olen jonkin verran katkera. Onneksi isäni ajatteli toisin ja sanoi kahden kesken, että oli hyvä, että olin hakeutunut terapiaan ja käytin lääkkeitä. Hänelle se ei ollut häpeä. Se auttoi minua todella paljon. (SKS 0251, sairaalajaksot 1980- ja 2010-luvuilla.)

Häpeän käsittelyllä on tärkeä osa myös psykoosista toipumisessa tai sen käsittelemättä jäämisellä vastaavasti sairauden kroonistumisessa. Potilaan läheisillä on keskeinen rooli siinä, miten sairauden aikaisen toiminnan aiheuttamia häpeän tunteita on mahdollista prosessoida ja lieventää (vrt. Lidman 2011, 273). Perheenjäsenien antaman tuen turvin moni on selviytynyt vaikeuksistaan ja alkanut jopa pitää sairaala-aikaa opettavaisena kokemuksena. Tällöin sairaala-aikaan liittyvä häpeä jää tapahtumasidonnaiseksi, eikä muutu sisäistetyksi, omaa identiteettiä muuttavaksi häpeäksi. Joissain tapauksissa taas suhteet perheenjäseniin ylläpitävät häpeää - perhe voi sairauden salailulla alleviivata sairauden hävettävyyttä, mikä usein tuntuu sairastuneesta itsestään loukkaavalta, tai edustaa esimerkiksi väkivaltaa tai seksuaalista hyväksikäyttöä. Näissä tapauksissa häpeästä toipumisen on muistoissa kuvattu edellyttäneen välien katkaisua tiettyihin omaisiin.

\section{Häpeä ja psykiatrinen hoitojärjestelmä}

Useat muistot kuvaavat sairaalassa koettua kaltoinkohtelua, joka on aiheuttanut vahvoja häpeän ja arvottomuuden tunteita. Häpeä on sosiaalisen kontrollin keino, joten se on tehokas kurinpidollinen väline myös mielisairaalassa. Muisteluaineistoissa toistui hoitohenkilökunnan vallankäytön kohteena oleminen, joka konkreettisimmin ilmeni pakkolääkityksenä ja muina pakkokeinoina. Seuraava runomuotoinen muisto kertoo, miten tämä jättää jälkensä potilaan olemukseen:

Potilaan ryhti/ on kääntäen verrannollinen/ siihen, kuinka paljon/ hoitajat häntä/ pompottelevat/ Valta sokaisee/ ja ehdoton valta/ sokaisee ehdottomasti/ Siksi me olemme tällaisia/ Niin luulen (SKS 0454, sairaalajakso 2010-luvulla).

Pakkokeinojen uhri kokee usein myös fyysistä kipua. Lidmanin $(2011,238)$ mukaan kipu lisää häpeän tunteita erityisesti silloin, kun sitä joutuu kärsimään yleisön edessä tai kun kipua aiheuttaneen toimenpiteen seuraukset jäävät näkymään kehoon. Monet lääkityksen seuraukset, kuten lisääntynyt syljeneritys, ylipainon kertyminen sekä varsinkin aiemmin käytössä olleisiin lääkkeisiin liittyneet silmien veto-oireet ja ilmeettömyys (Huttunen ja Raaska 
2015) vaikuttavatkin mielenterveyskuntoutujan ulkoiseen olemukseen stigmaa ja ennakkoluuloja vahvistavasti lisäten näin potilaiden kokemaa häpeää. Liiallisesta lääkityksestä väsynyt potilas ei aina jaksa huolehtia hygieniastaan tai reagoida ympäristöönsä, mikä syventää häpeän kierrettä. Koska lääkitys vaikuttaa konkreettisesti ihmisen kehoon ja ajatteluun, muuttuu sen välillisesti aiheuttama häpeä helposti sisäistetyksi - usein on mahdotonta erottaa sairauden oireita ja lääkityksen haittavaikutuksia omasta minuudesta.

Mielisairaalamuistoissaan monet kirjoittajat kuvaavat, kuinka raskaan lääkityksen vuoksi "eläimelliseksi" muuttuneet, fyysisesti ja psyykkisesti huonokuntoiset potilaat ovat joutuneet hoitajien epäinhimillisen kohtelun uhreiksi. Usein tätä kuvaamaan on käytetty eläinmetaforia, joihin liittyy monesti myös ajatus potilaiden likaisuudesta ja hoitajien potilaisiin kohdistuneesta fyysisestä inhon tunteesta. (Maanmieli 2018a.) Folkloristiikan tutkija Ulla Savolainen $(2017,127)$ pitää metaforien käyttöä muistelutekstissä myös merkkinä kaunokirjallisesta kerrontastrategiasta. Samalla kipeän kokemuksen kertominen helpottuu, ja sen voi etäännyttää omasta itsestä.

Osastolle tulevalle uudelle potilaalle muiden potilaiden lääkkeiden jähmettämä olemus sekä hoitajien kylmä suhtautumistapa voivat olla järkyttäviä. Nämä voimakkaan visuaaliset muistot ovat piirtyneet monien kirjoittajien mieliin hyvin selkeänä, kuten tässä yli neljänkymmenen vuoden takaisessa muistossa:

Monelta valui sylkeä ja he näyttivätkin ennemmin sairailta eläimiltä kuin ihmisiltä (SKS 0390, sairaalajakso 1970-luvulla).

Seuraava jo 12-vuotiaana mielisairaalaan joutuneen nuoren naisen muisto kuvaa hoidossa koettuja traumaattisia tapahtumia. Tässä katkelmassa kuvataan kertomisen hetkellä kahden vuoden takaista, voimakkaan kehollista traumamuistoa:

8 vuoden ajan käytössäni ollut vahva psyykelääkitys jouduttiin äkillisesti lopettamaan. [...] vieroitusoireet jysähtivät kunnolla päälle. [...] Makasin sängyllä ja yhtäkkiä menetin täysin kontrollin kehooni ja mieleeni. Pääni sisällä myllersi jotain painajaismaisen sekavaa, muistan äärimmäisen voimakkaan pelon tunteen. Pyysin hoitajalta apua, uudestaan ja uudestaan. Vaikeroin ja kehoni kouristeli voimakkaasti, en pystynyt pidättelemään tai kontrolloimaan sitä. [...] Ojensin kättäni hoitajaa kohti toivoen, että hän auttaisi minut seisaalleni. Hoitajan reaktiossa oli jotain vastenmielistä, hän kavahti taaksepäin kuin olisin saastainen eläin. (SKS 0482, sairaalajakso 2010-luvulla.)

Pitkään alalla toimineelle hoitotyöntekijälle potilaiden rajutkin reaktiot ja vahvat tunteet voivat näyttäytyä tavanomaisina, kun ne potilaalle itselleen ovat äärimmäisen pelottavia ja järkyttäviä. Sairaalaympäristöön joutuessaan ihminen on muiden armoilla aivan uudessa tilanteessa. Silloin hoitohenkilökunnan pienetkin kyllästymistä tai ärsyyntymistä ilmaisevat eleet ja sanavalinnat saavat usein suuren painoarvon ja potilas tulkitsee ne herkästi merkiksi omasta vastenmielisyydestään. Näin ne voivat lisätä sisäistettyä häpeää ja vaikeuttaa toipumista.

Yleensä sairaalahoito esitelläänkin aineistossa häpeää tuottavana asiana. Muistojen joukossa on kuitenkin poikkeuksia, joissa kerrotaan sairaalahoidon lievittäneen häpeää. Yksi kirjoittajista kertoo pystyneensä sairaalassa vihdoin paljastamaan kipeän perhesalaisuuden, seksuaalisen hyväksikäytön, ja saaneensa myös realistisemman käsityksen siitä, mitä 
mielenterveysongelmat ovat. Aiemmista salausaikeistaan huolimatta kirjoittaja on myös pystynyt kertomaan muille ihmisille sairaalajaksostaan:

Matkalla jo tiesin, että olen menossa "maailmaan" jossa kehtaan kertoa lapsuudestani... Olin hoidossa kuusi viikkoa. Tämän jakson aikana kerroin siskoilleni ja vanhemmilleni hyväksikäytöstä. Sisarukset olivat kokeneet saman. Samoin äiti. Kaikki [...] lukivat kirjoittamansa kirjeen hyväksikäyttäjälle. Vihdoin näin sisaruksissani surua, katkeruutta, vihaa. Saimme murrettua salaisuuden osastojakson aikana. (SKS 0357, sairaalajakso 2000-luvulla.)

Monissa muistoissa kuvataan myös hyvän hoitosuhteen mahdollistaneen häpeän käsittelyn. Joissain tapauksissa yksikin empaattinen ja kuunteleva hoitotahon edustaja tai muu luottamuksellinen ihmissuhde on mahdollistanut toipumisen alkamisen, kun kipeiden tunteiden prosessointiin on saanut tukea.

Häpeän vastavoimana voidaan pitää toivoa, ja toivoa ylläpitävä hoitosuhde voi helpottaa häpeän tunteita (Parpola 2013, 282). Tämä käy konkreettisesti ilmi muisteluteksteissä: 2000-luvulle sijoittuvia mielisairaalamuistojaan kuvaava kirjoittaja kertoo, miten ensimmäinen sairaalajakso oli kauhistuttava, mutta toisen, onnistuneen ja empaattista hoitoa tarjonneen sairaalajakson sekä tätä seuranneen psykoterapian ansiosta hän on alkanut nähdä oman sairastumisensa myös tärkeänä ja kasvattavana kokemuksena.

\section{Mielisairaalamuistojen keruu stigman purkajana ja häpeän lieventäjänä}

Sosiaalityön tutkija Tuija Eronen $(2012,46,103)$ tiivistää, että häpeän tunne on liitetty usein tabuihin, salaamiseen ja vaikenemiseen. Sosiaalisesti ja kulttuurisesti legitiimit tunteet määritellään eri aikoina ja erilaisissa narratiivisissa ympäristöissä eri tavoin, mikä vaikuttaa tunteiden kerrottavuuteen. SKS:n muistelukeruu on ollut osaltaan hälventämässä häpeäleimaa. Keruukutsun julkistaminen on välittänyt viestin, että mielisairaalaan liittyvistä kokemuksista saa kertoa kuten mistä tahansa muistakin elämänvaiheista. Muistitiedon tutkijat (Pöysä 2006, 221; Fingerroos ja Haanpää 2006, 29) ovatkin korostaneet muistitiedon roolia akateemisen historiantutkimuksen piiloon jättämien seikkojen esiin nostajana. Muistelutekstin kirjoittajien kokemusten nostaminen yleiseen tietoisuuteen ja niiden tutkiminen esimerkiksi narratiivisen analyysin keinoin voi rohkaista muitakin käsittelemään kokemuksiaan lähipiirissä tai julkisesti.

Muistoissa kuvataan, miten mielisairaalakokemusten kertominen on mahdollistunut vasta pitkän henkilökohtaisen prosessoinnin kautta. Eräs kirjoittajista kuvaa koko elämäänsä sävyttävää kokonaisvaltaista sisäistettyä häpeää. Hän kokee, ettei vakavista mielenterveysongelmista ole ollut mahdollista avoimesti puhua kenellekään, koska niihin liittyy niin vahva stigma. Tämä on kapeuttanut sosiaalista elämää. Keruukutsun hän kokee lupana vihdoin kertoa vaietuista asioista. Kirjoittaminen voidaan näin nähdä symbolisena rajan ylittämisenä (Pöysä 2015, 126).

Joillekin olen saattanut paljastaa, että joskus olen ollut hieman hoidossa ja syönyt psyykelääkkeitä, "kun on ollut kriisi päällä", mutta tuollaiseen ympäripyöreään mitään kertomattomaan ilmaisuun se on jäänyt. Eihän sitä - Herra Jumala! - voi kahvipöydässä ilmoittaa olevansa skitsofreenikko. [...] Julkinen, sosiaalinen elämäni on ollut silkkaa peittelyyn ja valheeseen kietoutumista, siksi annan nyt "totuuden" puhua. (SKS 251, sairaalajaksot 1980- ja 2010-luvuilla.) 
Jotkut kirjoittajat kuvaavat, miten kirjoittaminen on ollut muutenkin huojentava tapa käsitellä mielenterveyteen liittyviä vaikeita kokemuksia ja lieventää näin niistä koettua häpeää (Maanmieli 2018b). Monissa sairaaloissa hoidossa ollut nainen kertoo kirjoittamisharrastuksensa tärkeimmäksi motiiviksi häpeän hälventämisen. Hän on julkaissut omakustanteen, jossa tarjotaan kokemustietoa mielenterveysongelmista. (SKS 0440, sairaalajaksoja 1980-2010-luvuilla.) Monilla muillakin kirjoittajilla on ollut emansipatorisia motiiveja osallistua kirjoituskeruuseen: he kertovat haluavansa tehdä psykiatrisen hoidon epäkohtia näkyväksi ja murtaa mielen sairauksien häpeäleimaa. Muistikeruuseen osallistuminen voi myös olla osa laajempaa yhteiskunnallisen vaikuttamisen halua tai kannustaa siihen. Näin omia vaikutusmahdollisuuksiaan kuvaa mielenterveyspotilaan sisar, joka myöhemmin opiskeli mielenterveyshoitajaksi:

En tiedä olisinko onnellisempi, jos en olisi noita häpeän leimoja saanut, tai itse antanut iskeä, iholleni. Onhan sanottu: "Mikä ei tapa, se vahvistaa". Todennäköisesti minusta on tullut rohkeampi ja monessa mielessä kestävämpi. [...] Keskustellessani samansuuntaisissa elämäntilanteissa eläneiden ihmisten kanssa, voin olla tietämättäni terapeuttina ja saatan olla ainoa, jolle keskustelukumppani on kertonut sukunsa "häpeällisestä" mielisairaudesta. (SKS 0427, muiston ajankohtaa ei mainittu.)

\section{Lopuksi}

Vaikka keruukutsu on auttanut monia kirjoittajia purkamaan vaiettuja perhesalaisuuksia ja jakamaan kokemuksiaan, on keruukutsun kautta muodostunut aineisto toisaalta väistämättä valikoitunutta. Kutsu on saavuttanut enimmäkseen inmisiä, jotka lukevat mielenterveysalan julkaisuja tai osallistuvat mielenterveystapahtumiin ja ovat niin ollen ehkä muutenkin jo käsitelleet häpeän tunteitaan. Keruuseen vastaaminen vaatii riittävää toimintakykyä ja motivaatiota. Oletan, että keruu ei ole tavoittanut niitä mielisairaaloiden entisiä potilaita, jotka kipeimmin kaipaisivat häpeänsä käsittelyä ja siitä vapautumista. Muistoja on kuitenkin kerätty myös kahdessa hoito- ja kuntoutuslaitoksessa. Tätä kautta muistoja ovat päässeet jakamaan nekin mielisairaaloita potilaan roolissa muistelevat kirjoittajat, jotka eivät oma-aloitteisesti olisi keräykseen osallistuneet. Myös väljästi laaditun keruukutsun mahdollistama vapaa käsittelytapa ja mahdollisuus vastata anonyymisti ovat varmasti madaltaneet osallistumisen kynnystä. Kipeitä kokemuksia on muistelutekstissä voinut etäännyttää esimerkiksi runomuotoisen ilmaisutavan tai metaforien kautta (Maanmieli 2018a ja 2018b).

Sairaalakokemukset ovat usein hyvin kehollisia ja niihin liittyvät muistot ovat niin sanottua hiljaista tietoa, jonka sanallistaminen on haasteellista (ks. Uotinen 2010, 86-87). Tämä näkyy myös keräykseen lähetetyissä muistoissa niiden aukkoisuutena ja sivuutettuina ajanjaksoina tai teemoina. Historioitsijat Antti Häkkinen ja Mikko Salasuo $(2015,13)$ kuvaavatkin aukkoisten ja häpeään kytkeytyvien aineistojen tutkimista salapoliisityönä, jossa erilaisia vihjeitä, johtolankoja ja ensin epäolennaisilta vaikuttavia yksityiskohtia yhdistellään uutta ymmärrystä tuottavaksi kokonaisuudeksi. Tarkka lähiluku ja monitieteellinen tutkimus saavat aineistosta esiin asioita, joita aineiston pintapuolinen tarkastelu ei paljasta. Muistoissa kuvatut tunteet ovat intensiteetiltään erilaisia ja ilmenevät eri tavoin riippuen siitä, mistä perspektiivistä mielisairaalakokemuksia tarkastellaan. Siksi psykologi Ronnie Janoff-Bulmanin (1979) jako tapahtumasidonnaiseen ja sisäistettyyn häpeään onkin relevantti, kun eri muistelijaryhmien tekstejä analysoidaan tulevissa tutkimuksissa. Lähiluku voi paljastaa esimerkiksi sisäistetyn häpeän rakentumisen lapsuuden mielisairaalaan tai läheisten psyykkisiin 
sairauksiin liittyvien muistojen, hoidossa koetun kaltoinkohtelun ja läheisten torjuvan suhtautumisen kautta. Tämä on tulevissa tutkimuksissa tärkeä kartoitettava teema.

Henkilökunnan muistoja keruuseen lähetettiin huomattavan vähän, vaikka oletan tiedon keräyskutsusta tavoittaneen heidät potilaita paremmin. Näistäkin vastaajista vain osa käsitteli häpeän tai syyllisyyden tunteitaan. Hoitohenkilökunnan jäsenistä monet ovat jättäneet arkistoon yhteystietonsa, joten muistelijoiden haastattelu voisi olla yksi toimiva keino syventää hoitohenkilökunnan kokemusten analyysia. Aihe on tärkeä, sillä potilaiden häpeän tunteiden helpottamiseen pyrittäessä on mielestäni otettava huomioon myös hoitohenkilökunnan tuntema häpeä ja sen mahdollinen vaikutus hoitotyöhön.

Syrjivien ja leimaavien kulttuuristen käsitysten ja käytänteiden taustan ja niiden rakentumisen tuominen näkymiin ja tekeminen ymmärrettäväksi mahdollistaa käsitysten työstämisen, purkamisen ja parhaassa tapauksessa muuttamisen (Kinnunen ja Hänninen 2016; Jäntti et al. 2019). Kulttuurisen mielenterveystutkimuksen avulla on mahdollista nostaa esiin käytänteitä ja totuttuja ajattelutapoja, joiden kautta mielenterveysongelmiin liittyvää stigmaa tuotetaan ja uusinnetaan. Tulevissa tutkimuksissa voisi kartoittaa, kuinka empaattisen ja ihmisen traumataustan huomioivan psykiatrisen hoidon avulla voidaan ehkäistä potilaan omanarvontunteen laskemista, jolloin mielen sairauksien ja sairaalahoidon kulttuurisen stigman merkitys pienenee.

\section{Muistelukeruuaineisto}

Suomalaisen Kirjallisuuden Seuran arkisto. Muistoja ja kokemuksia mielisairaalasta -muistokeruuaineisto. Koottu 2014-2015 Kulttuurisen mielenterveystutkimusverkoston ja Suomalaisen Kirjallisuuden Seuran kansanrunousarkiston yhteistyönä.

\section{Kirjallisuus}

Eronen, Tuija. 2012. Lastenkoti osana elämäntarinaa: Narratiivinen tutkimus lastenkodissa asuneiden kertomuksista. Tampere: Tampere University Press. http://tampub.uta.fi/ handle/10024/66881.

Fingerroos, Outi ja Riina Haanpää. 2006. "Muistitietotutkimuksen ydinkysymyksiä." Teoksessa Muistitietotutkimus: Metodologisia kysymyksiä, toimittaneet Outi Fingerroos, Riina Haanpää, Anne Heimo ja Ulla-Maija Peltonen, 25-48. Helsinki: Suomalaisen Kirjallisuuden Seura.

Huttunen, Matti O. ja Kari Raaska. 2015. "Psyykenlääkkeiden käytön sudenkuopat." Duodecim 131(18): 1651-1657.

Häkkinen, Antti ja Mikko Salasuo. 2015. "Johdanto." Teoksessa Salattu, hävetty, vaiettu: Miten tutkia piilossa olevia ilmiöitä, toimittaneet Antti Häkkinen ja Mikko Salasuo, 9-17. Tampere: Vastapaino.

Janoff-Bulman, Ronnie. 1979. “Characterological versus behavioral self-blame: Inquiries into depression and rape." Journal of Personality and Social Psychology 37: 1798-1809. http:// dx.doi.org/10.1037/0022-3514.37.10.1798. 
Joutsenniemi, Kaisla. 2011. "Lähiomaiset ja häpeäleima." Teoksessa Irti häpeäleimasta, toimittaneet Jyrki Korkeila, Kaisla Joutsenniemi, Eila Sailas ja Jorma Oksanen, 43-51. Porvoo: Bookwell Oy.

Jäntti, Saara, Kirsi Heimonen, Sari Kuuva ja Annastiina Mäkilä (toim.). 2019. Hulluus ja kulttuurinen mielenterveystutkimus. Jyväskylän yliopisto.

Kainulainen, Siru ja Viola Parente-Čapkova (toim.). 2011. Häpeä vähän! Kriittisiä tutkimuksia häpeästä. Turku: Utukirjat, Turun yliopisto.

Kallinen, Kati, Henna Pirskainen ja Susanna Rautio. 2015. Sensitiivinen tutkimuksessa: Menetelmät, kohderyhmät, haasteet ja mahdollisuudet. Tallinna: United Press Global.

Kinnunen, Anna. 2013. "Kohtaamisia kerronnan tilassa: Mielisairaalapotilaita koskevan muistelukerronnan rakentuminen." Elore (20)2: 33-53. https://doi.org/10.30666/ elore.79086.

Kinnunen, Anna ja Kirsi Hänninen. 2016. "Saatteeksi: Hulluus kulttuurisena ilmiönä ja tutkimuskohteena." Elore 23(1). https://doi.org/10.30666/elore.79239.

Kivimäki, Ville. 2013. Murtuneet mielet: Taistelu suomalaissotilaiden hermoista 1989-1945. Helsinki: Werner Söderström Osakeyhtiö.

Korkeila, Jyrki, Kaisla Joutsenniemi, Eila Sailas ja Jorma Oksanen (toim.). 2011. Irti häpeäleimasta. Porvoo: Bookwell Oy.

Korvenniemi, Anu (toim.). 2013. Toisen maailman kartalla: Kirjoituksia psykoosista. Helsinki: ntamo.

Kulmala, Anna. 2006. Kerrottuja kokemuksia leimatusta identiteetistä ja toiseudesta. Tampere: Tampere University Press. http://urn.fi/urn:isbn:951-44-6615-2.

Kuuva, Sari. 2018. "Mielisairaalan varjoista: Nostalgia ja melankolia mielisairaalaalueella asuneiden lapsuusmuistoissa." Jargonia 16(31): 12-40. https://jyx.jyu.fi/ handle/123456789/58335.

Leeming, Dawn ja Mary Boyle. 2004. "Shame as a social phenomenon." Psychology and Psychotherapy: Theory, Research and Practice 77(3): 375-396. https://doi. org/10.1348/1476083041839312.

Lidman, Satu. 2011. Häpeä: Nöyryyttämisen ja häpeän jäljillä. Porvoo: Bookwell Oy.

Maanmieli, Karoliina. 2018a. "Luovat terapiat ja empaattisen kohtaamisen kaipuu suomalaisten mielisairaalamuistojen valossa." Kirjallisuusterapia 26(1): 5-9.

Maanmieli, Karoliina. 2018b. "Suomalaiset käenpesät: Väkivallan metaforat ja traumakokemuksen kuvaus mielisairaalamuistoissa." Psykoterapia 37(1): 37-48.

Makkonen, Elina. 2005. "Lapsuus menneen ja nykyisen vuoropuhelussa: Kaltimolaisten muistelupuheen tarkastelua." Teoksessa Leikkikentiltä: Lastenperinteen tutkimuksia 2000-luvulta, toimittanut Helena Saarikoski, 83-104. Helsinki:Suomalaisen Kirjallisuuden Seura.

Malinen, Ben. 2018. Häpeän monet kasvot. Helsinki: Kirjapaja.

Malinen, Ben. 2010. The Nature, Origins, and Consequences of Finnish Shame-Proneness: $A$ Grounded Theory Study. Helsingin yliopisto.

Mertanen, Heli. 2009. "Poeettinen ja metaforinen kieli hoitotyössä." Teoksessa Sanat että hoitaisimme: Terapeuttinen kirjoittaminen, toimittanut Juhani Ihanus, 233-254. Helsinki: Duodecim. 
Niedenthal, Paula, Silvia Krauth-Gruber ja Francois Ric. 2006. Psychology of emotion: Interpersonal, experiential, and cognitive approaches. New York: Psychology Press.

Parpola, Antti. 2013. Toivo/Häpeä: Psykiatria modernissa Suomessa. Suomen Psykiatriyhdistys.

Paukkunen, Antti. 2013. Vähemmän häpeää, enemmän elämää: Tutkielma häpeästä ja sen terapeuttisesta hoitamisesta. Pro gradu -tutkielma. Tampereen yliopisto. https://tampub. uta.fi/bitstream/handle/10024/84594/gradu06733.pdf?sequence=1\%20s.\%2014

Plummer, Ken. 2001. Documents of Life 2: An Invitation to a Critical Humanism. London: Sage.

Pohjola, Anneli. 2002. "Pahan säikeitä auttamistyössä."Teoksessa Pahan kosketus: Ihmisyyden ja auttamistyön varjojen jäljillä, toimittaneet Johanna Hurtig ja Merja Laitinen, 42-62. Jyväskylä: PS-kustannus.

Pöysä, Jyrki. 2006."Kilpakirjoitukset muistitietotutkimuksessa."Teoksessa Muistitietotutkimus: Metodologisia kysymyksiä, toimittaneet Outi Fingerroos, Riina Haanpää, Anne Heimo ja Ulla-Maija Peltonen, 221-244. Helsinki: Suomalaisen Kirjallisuuden Seura.

Pöysä, Jyrki. 2015. Lähiluvun tieto: Näkökulmia kirjoitetun muistelukerronnan tutkimukseen. Joensuu: Suomen Kansantietouden Tutkijain Seura.

Rechardt, Eero ja Pentti Ikonen. 1994. "Häpeä psyykkisen lamaannuksen aiheuttajana." Duodecim 10(3): 278-286.

Savolainen, Ulla. 2015. Muisteltu ja kirjoitettu evakkomatka: Tutkimus evakkolapsuuden muistelukerronnan poetiikasta. Joensuu: Suomen Kansantietouden Tutkijain Seura.

Silfver-Kuhalampi, Mia. 2009. The sources of moral motivation: Studies on empathy, guilt, shame and values. Helsinki: University of Helsinki.

Siltala, Juha. 1994. Miehen kunnia: Modernin miehen taistelu häpeää vastaan. Helsinki: Otava.

Siltala, Pirkko. 2016. Taakkasiirtymä: Trauman siirto yli sukupolvien. Tampere: Hermes Oy.

Stone, Brendan. 2004. "Towards a Writing without Power: Notes on the Narration of Madness." Auto/Biography Studies 12(1): 16-32. http://dx.doi.org/10.1191/0967550704ab002oa.

Tomkins, Silvan S. 1963. Affect, Imaginery, Consciousness II: The Negative Affects. New York: Springer.

Uotinen, Johanna. 2010. "Aistimuksellisuus, autoetnografia ja ruumiillinen tietäminen." Elore 17(1): 86-95. https://doi.org/10.30666/elore.78851.

FT Karoliina Maanmieli tutkii suomalaisten mielisairaalamuistoja Koneen säätiön rahoittamassa Muistoihin kaivertuneet tilat -hankkeessa kirjoittamisen oppiaineessa Jyväskylän yliopistossa. 